\title{
Partisipasi Masyarakat Lokal Dalam Pengelolaan Wisata Bahari Di Pantai Semawang Kelurahan Sanur Kelod
}

Putu Devi Oktaviani a, 1, Ida Ayu Suryasih a, 2

${ }^{1}$ putudev@gmail.com, ${ }^{2}$ idaayusuryasih@unud.ac.id

a Program Sarjana S1 Destinasi Pariwisata, Fakultas Pariwisata,Universitas Udayana, Jl. Dr. R. Goris, Denpasar, Bali 80232 Indonesia

\section{Abstract}

Tourism development in Denpasar, especially maritime tourism at Semawang Beach in Sanur Kelod has encourage the local community to participate in developing tourism on Semawang Beach. This phenomenon has create participation of local communities in the management of maritime tourism. This research aim to examine participation of local communities in the management of maritime tourism at Semawang Beach in Sanur Kelod. The advantage that are expected to be achieved from this research are academic and practical advantages.

This research is located at Semawang Beach in Sanur Kelod. The limits on the scope of this research includes motivation of local communities in management of maritime tourism and participation of local communities in the management of maritime tourism. Type of research data is in the form of qualitative and quantitative. Source of data obtained from primary and secondary data. Collection data techniques using observation, in-depth interview and documentation. Snowball sampling method has been used to determine informant and respondent

The result of this research shows that motivation of local communities in the management of maritime tourism at Semawang Beach in Sanur Kelod is motivation to improve the welfare of the society and the mutual relationship between the maritime tourism with the local citizen. The type of local communities participation in the management of maritime tourism at Semawang Beach in Sanur Kelod are divide by three domains, such as : (1) economic participation, by the local communities work in the field of marine tourism, (2) environtment participation, by implementing thebeach clean program at Semawang Beach, coral reef cleanup program, village deliberations are held to discuss various issues in the environment, participation of local communities in the efforts to protect the environment around Semawang Beach, participation of local communities in lending of vacant land as parking lots, (3) social culture participation, laying of typical Balinese statues and introduce the melukat culture to the tourist.

\section{Keywords: Participation, local communities, sustainable tourism, maritime tourism, Semawang Beach}

\section{PENDAHULUAN}

Bali merupakan sebuah provinsi di Indonesia yang telah memiliki reputasi sebagai destinasi wisata yang terdiri atas berbagai macam atraksi. Daya tarik wisata yang beragam merupakan faktor penarik bagi wisatawan untuk mengunjungi Bali. Tingginya jumlah kunjungan wisatawan ke Bali, secara langsung telah memberikan kontribusi terhadap tingkat penerimaan negara melalui devisa. Sektor pariwisata, merupakan sektor yang sangat cepat tumbuh dan merupakan salah satu sektor yang mampu membuka peluang baik untuk mencari pekerjaan maupun membuka lapangan kerja.

Berkat perkembangan akses dunia global telah membuat kegiatan berwisata menjadi lebih mudah. Kegiatan tour dengan skala kecil maupun skala besar bisa dengan mudah dirancang untuk memenuhi kebutuhan wisatawan. Wisatawan dapat dengan mudah menentukan kapan dan atraksi apa yang ingin dikunjungi. Ironisnya, kemudahan akses dunia global melalui jaringan internet membuat 'invasi' wisatawan, khususnya wisatawan yang datang dalam kelompok besar semakin menjadijadi. Fenomena ini kerap dikenal dengan istilah mass tourism.

Bali merupakan pulau yang memiliki kapasitas atau daya dukung yang terbatas, sementara mass tourism dengan ciri khasnya yaitu wisatawan dengan jumlah besar tentu menjadi ancaman yang serius. Jumlah wisatawan yang besar, berbanding lurus dengan peningkatan kebutuhan akan air bersih, akomodasi dan akses ruang publik. Masyarakat lokal, secara langsung 
maupun tidak langsung menjadi pihak yang akan merasakan imbas dari kegiatan pariwisata yang berlebihan. Masyarakat akan merasakan penurunan jumlah air tanah dan mau tidak mau harus membagi akses ruang publik seperti pantai hingga tempat bersembahyang dengan wisatawan.

Untuk mencegah hal ini semakin meluas, kemudian muncul konsep alternative tourism. Alternative tourism atau wisata alternatif pada intinya merupakan bentuk pariwisata yang dirancang agar ramah lingkungan dan menghormati nilai sosial dan cultural masyarakat yang memberikan kesempatan bagi wisatawan dan tuan rumah untuk menikmati pengalaman positif (Wearing dan Neil, 1999).

Setiap daerah di Bali memiliki potensi alam yang berbeda. Kota Denpasar tidak dipungkiri sebagai daya tarik wisata karena memiliki beberapa daya tarik wisata yang dapat menarik wisatawan. Salah satu contoh daya tarik wisata di Kota Denpasar adalah wisata bahari di pantai, khususnya adalah Pantai Semawang yang berada di Kelurahan Sanur Kelod.

Pantai Semawang yang tenang di tepi, namun berombak pada bulan-bulan tertentu. Hal ini membuat Pantai Semawang kerap dikunjungi untuk sekadar bermain kano, maupun surfing. Faktanya, Pantai Semawang memiliki potensi yang jauh lebih besar. Pantai Semawang juga memiliki pemandangan bawah laut yang dapat dilihat dari permukaan sehingga memungkinkan wisatawan untuk melakukan snorkeling apabila tidak memiliki sertifikasi menyelam.

Keadaan Pantai Semawang yang ideal untuk dimanfaatkan sebagai wisata bahari, sepatutnya diimbangi oleh pengelolaan dari sumber daya manusia yang kompeten. Masyarakat setempat merupakan pihak yang sangat ideal untuk mengelola usaha-usaha yang berkaitan dengan wisata bahari, terutama di era seperti sekarang dimana persaingan global semakin meningkat. Dengan mengetahui hal tersebut, dapat disusun strategi untuk menstimulasi masyarakat untuk turut serta dalam pengelolaan wisata bahari.

\section{KEPUSTAKAAN}

Ada dua penelitian yang digunakan sebagai bahan acuan untuk melakukan penelitian, yaitu penelitian oleh Dalimunthe (2007) dalam sebuah tesis yang berjudul "Partisipasi Masyarakat dalam Pengembangan Potensi Wisata Bahari Pantai Cermin Kabupaten Serdang Bedagai" mengulas mengenai partisipasi masyarakat pesisir. Dalam penelitian tersebut, dijelaskan bahwa di Kabupaten Serdang Bedagai, telah terdapat Program Pemberdayaan Ekonomi Masyarakat Pesisir (PEMP) yang bertujuan untuk meningkatkan kesejahteraan masyarakat pesisir. Penelitian tersebut juga menunjukkan bahwa pengembangan pariwisata Pantai Cermin telah berpengaruh terhadap perbaikan ekonomi masyarakat secara signifikan. Namun disisi lain, karakter masyarakat Pantai Cermin juga mulai berubah seiring waktu. Masyarakat secara sadar dan sukarela bersama-sama menjaga lingkungan hidup di Pantai Cermin sebagai implikasi dari pengembangan pariwisata di Pantai Cermin.

Persamaan dari penelitian tersebut dengan penelitian ini terletak pada fokus penelitian yang sama, yaitu partisipasi masyarakat dan jenis pariwisata yang diteliti, yaitu wisata bahari. Partisipasi masyarakat yang merupakan fokus penelitian sebelumnya adalah keikut 
sertaan masyarakat dalam pengelolaan wisata bahari. Perbedaan penelitian ini dengan penelitian sebelumnya adalah lokasi penelitian, dimana penelitian sebelumnya berlokasi di Pantai Cermin Kabupaten Serdang Bedagai, sementara penelitian ini berlokasi di Pantai Semawang Kota Denpasar. Selain itu, yang ditonjolkan dalam penelitian sebelumnya adalah partisipasi masyarakat dalam pengembangan potensi, sementara yang menjadi fokus penelitian dalam penelitian ini adalah partisipasi masyarakat dalam pengelolaan yang telah berlangsung selama ini.

Sementara Ajustawan (2005) dalam sebuah skripsi yang berjudul "Keberadaan Jasa Penyewaan Kano sebagai Penjunjang Kepariwisataan di Pantai Semawang Kelurahan Sanur Denpasar" menjelaskan mengenai keberadaan jasa penyewaan kano dalam menunjang aktivitas kepariwisataan di Pantai Semawang. Hasil penelitian tersebut menunjukkan bahwa jasa penyewaan kano merupakan usaha yang menguntungkan baik untuk menunjang aktivitas pariwisata, serta memberikan kesempatan bagi masyarakat lokal untuk mendapatkan keuntungan dari segi ekonomi.

Penelitian tersebut merupakan penelitian yang berbeda dengan penelitian ini ditinjau dari aspek lingkup penelitian. Penelitian tersebut terbatas pada keberadaan jasa penyewaan kano, sementara penelitian ini mengkaji partisipasi masyarakat dalam aktivitas wisata bahari yang lebih luas, tidak hanya terbatas pada usaha penyewaan kano. Adapun penelitian tersebut memiliki persamaan dengan penelitian ini, yaitu lokasi penelitian yang samasama berlokasi di Pantai Semawang Denpasar.

\section{METODE PENELITIAN}

\subsection{Lokasi Penelitian}

Penelitian ini berlokasi di Pantai Semawang, Kelurahan Sanur Kelod. Pantai Semawang merupakan pantai yang berada di antara Pantai Mertasari dan Pantai Karang. Pantai Semawang berada di dalam area Kota Denpasar, sekitar 15 km dari Bandara Ngurah Rai. Lokasi Pantai Semawang sangat strategis karena dapat dicapai dengan mudah baik dengan sepeda motor maupun mobil.

\subsection{Jenis dan Sumber Data}

Menurut Sugiyono (2003) jenis data dapat dibagi menjadi dua, yaitu data kualitatif dan data kuantitatif. Data Kualitatif merupakan data yang berbentuk kata, kalimat, skema dan gambar, sedangkan data kuantitatif merupakan data yang berbentuk angka atau data kualitatif yang diangkakan. Adapun jenis data yang digunakan dalam penelitian ini adalah:

- Data Kualitatif yaitu data yang meliputi sejarah dan gambaran umum yang mencakup faktor faktor pendorong dan partisipasi masyarakat lokal dalam pengelolaan wisata bahari di Pantai Semawang kelurahan Sanur Kelod.

- Data Kuantitatif yaitu data statistik yang berupa jumlah kunjungan wisatawan ke Bali dan data jumlah kunjungan wisatawan ke Kota Denpasar.

Menurut Lofland dan Lofland (1984, dalam Moelong 2012), bahwa sumber data utama dalam penelitian kualitatif adalah kata - kata dan tindakan. Selebihnya adalah data tambahan seperti dokumen dan lain - lain. Adapun sumber data yang digunakan dalam penelitian ini adalah : 
- Data Primer, yaitu data yang diperoleh dengan jalan dikumpulkan sendiri oleh peneliti dan langsung dari objek yang diteliti (Kusmayadi dan Sugiarto, 2000). Data primer dalam penelitian diperoleh secara langsung dari hasil wawancara dengan narasumber atau informan yang dianggap berpotensi dalam memberikan informasi yang relevan di Pantai Semawang.

- Data Sekunder, yaitu data yang merupakan hasil dari pengumpulan orang atau instansi lain dalam bentuk publikasi (Kusmayadi dan Sugiarto, 2000). Data sekunder dalam penelitian ini diperoleh dari pihakpihak yang berkompeten dan instansi - instansi terkait, seperti data kunjungan wisatawan yang berkunjung ke Bali dan data kunjungan wisatawan yang berkunjung ke kota Denpasar. Dan berupa literature dan dokumen yang terdapat pada bahan bacaan, bahan pustaka, dan laporan - laporan penelitian.

\subsection{Teknik Pengumpulan Data}

Data yang diperlukan dalam penelitian ini dikumpulkan menggunakan beberapa macam cara. Adapun metode pengumpulan datanya adalah sebagai berikut :

- Observasi yaitu upaya yang dilakukan oleh pelaksana penelitian kualitatif untuk merekam peristiwa dan kegiatan yang terjadi dengan menggunakan alat bantu atau tidak (Koenjaraningrat, 1997). Dalam penelitian ini observasi dilakukan di Pantai Semawang Kelurahan Sanur Kelod melalui pengamatan yang selanjutnya dimasukkan ke dalam catatan kecil.
- Wawancara mendalam merupakan teknik mengumpulkan data yang dilakukan dengan memberikan pertanyan-pertanyaan kepada informan berdasarkan pedoman wawancara yang telah dibuat (Bungin, 2003). Percakapan dilakukan oleh dua pihak yaitu pewawancara (interviewer) yang mengajukan pertanyaan dan terwawancara (interviewee) yang memberikan jawaban atas pertanyaan itu. Teknik ini dilakukan untuk memperoleh keterangan atau data yang lebih mendalam kepada pihak terkait seperti wawancara terhadap masyarakat lokal yang ada di Pantai Semawang dengan berpedoman dengan pertanyaanpertanyaan mengenai bentuk partisipasi dan motivasi masyarakat untuk berpartisipasi dalam pengelolaan.

- Dokumentasi adalah cara mengumpulkan data dengan mengklasifikasikan bahan-bahan tertulis yang berhubungan dengan masalah penelitian, baik dari sumber dokumen, maupun buku-buku, koran, majalah dan lain-lain (Nawawi,1995). Dalam penelitian ini, dokumentasi dilakukan dengan pengambilan dan pengumpulan data berupa catatan terdahulu mengenai wisata bahari Pantai Semawang dan gambar-gambar rekaman visual maupun audio yang bisa untuk memperkuat hasil penelitian ini.

\subsection{Teknik Penentuan Informan}

Snowball Sampling adalah teknik penentuan sampel yang mula-mula jumlahnya kecil, kemudian membesar (Sugiyono, 2011:68). Ibarat bola salju yang menggelinding yang lama-lama menjadi besar. Dalam penentuan 
informan, pertama-tama dipilih satu atau dua orang, tetapi karena dengan dua orang ini belum merasa lengkap terhadap data yang diberikan, maka peneliti mencari orang lain yang dipandang lebih tahu dan dapat melengkapi data yang diberikan oleh dua orang sebelumnya. Begitu seterusnya, sehingga jumlah informan semakin banyak.

Dalam penelitian ini, yang akan diwawancarai pertama kali adalah salah satu masyarakat lokal yang terlibat langsung dalam kegiatan wisata bahari, kemudian peneliti akan mewawancari seseorang yang ditunjuk oleh informan sebelumnya dengan pedoman wawancara yang sama hingga data yang diberikan dianggap jenuh.

\subsection{Teknik Analisis Data}

Adapun teknik analisis data yang diperlukan dalam penelitian ini adalah analisis deskriptif kualitatif. Analisis deskriptif kualitatif yaitu data yang secara operasional dianalisis dengan tiga langkah sistematis. Menurut Miles (2007) ketiga langkah sistematis tersebut adalah reduksi data, penyajian data dan penarikan kesimpulan. Sesuai dengan data yang diperlukan atau dikumpulkan dan teknik pengumpulan data tersebut, maka langkah-langkah analisis data dilakukan sebagai berikut :

- Reduksi data dilakukan dengan pemilihan,

pemusatan, penyederhanaan, pengabstrakan, dan transformasi data mentah yang muncul dari hasil catatan-catatan tertulis dilapangan. Pada tahap ini, perhatian terpusat pada data lapangan yang terkumpul. Data tersebut selanjutnya dipilih sesuai dengan relevansinya dengan penelitian. Selanjutnya, data yang dipilih disederhanakan dan selanjutnya diklasifikasikan sesuai sub-topik yang sesuai.

- Tahap penyajiian data dimana dalam penelitian ini, penyajian data dilakukan dalam bentuk teks naratif yang selanjutnya diringkas dalam bagan atau alur bentuk partisipasi masyarakat.

Penarikan kesimpulan dilakukan dengan melakukan penafsiran mengenai isi ringkas dari kesimpulan (Miles, 2007)

\section{HASIL DAN PEMBAHASAN \\ 4.1 Gambaran Umum}

Pantai Semawang berada di wilayah Kelurahan Sanur Kelod Kecamatan Denpasar Selatan, Kota Denpasar. Secara geografis, posisi Pantai Semawang sangat strategis dan dapat ditempuh hanya $10-15$ menit ( $3 \mathrm{~km})$ dari pusat kota denpasar, Pantai Semawang tidak begitu sulit ditemukan, karena letak dari Pantai Semawang sendiri sangat strategis, dan sangat mudah dicapai karena banyaknya kendaraan umum yang sangat ramai antara Semawang - Denpasar, tetapi Pantai Semawang jauh dari Bandara Internasional Ngurah Rai, yang hampir ditempuh dengan waktu 25-30 menit(18 km).

Kelurahan Sanur Kelod mempunyai penduduk sebanyak 965.088 orang yang terdiri dari masyarakat yang dahulu sebagian besar bekerja sebagai nelayan. Dalam kegiatan nelayan tradisional saat ini telah bergeser sesuai dengan paradigma perekonomian kerakyatan di sektor perikanan. Kelautan yang berbasis wisata bahari sangat cocok dikembangkan di wilayah Pantai Semawang Kelurahan Sanur Kelod. Dikarenakan adanya perkembangan usaha pariwisata bahari khususnya kegiatan rekreasi air (water sport). Nelayan tradisional sekarang 
sebagian beralih menjadi nelayan yang menyediakan jasa pelayanan dalam bidang penyewaan perahu untuk menunjang kegiatan wisata bahari.

Sektor wisata bahari yang semakin marak dikunjungi para wisatawan menghasilkan devisa Negara, sangat meyakinkan bagi Kelurahan Sanur Kelod mengangkat sektor ini sebagai sektor unggulan. Sektor ini memiliki berbagai atraksi kegiatan di bidang rekreasi pantai. Aktivitas rekreasi air yang ada di Pantai Semawang Kelurahan Sanur Kelod diantaranya sea walker, scuba diving, free diving, snorkeling.

\subsection{Motivasi Masyarakat Lokal Berpartisipasi dalam Pengelolaan Wisata Bahari di Pantai Semawang Kelurahan Sanur Kelod}

Adapun faktor - faktor yang menjadi motivasi masyarakat lokal Kelurahan Sanur Kelod berpartisipasi dalam pengelolaan pariwisata bahari di Pantai Semawang adalah sebagai berikut :

\section{- Motivasi untuk meningkatkan} kesejahteraan hidup

Sebelum adanya perkembangan pariwisata, masyarakat lokal kelurahan Sanur Kelod sebagian besar bermata pencaharian sebagai nelayan. Namun, seiring dengan pesatnya perkembangan pariwisata membawa pengaruh yang signifikan terhadap mata pencaharian masyarakat sendiri. Saat ini masyarakat lokal Kelurahan Sanur Kelod tidak hanya berprofesi sebagai nelayan saja, namun sudah banyak yang beralih menjadi pengusaha yang beralih dibidang wisata bahari, pemandu wisatawan, membuka usaha penjualan cinderamata, sebagai karyawan dibidang usaha bahari, serta sebagai karyawan hotel atau restoran yang berada di kelurahan Sanur Kelod. Namun, hal ini tidak terjadi di semua kalangan masyarakat lokal di kelurahan Sanur Kelod karena masih terdapat masyarakat lokal yang memiliki profesi sebagai nelayan. Alasan para nelayan berpindah profesi karena mereka termotivasi ingin meningkatkan kesejahteraan hidup agar menjadi lebih baik. Atas dasar pemikiran ini, masyarakat lokal kelurahan Sanur Kelo jugad turut serta terlibat dalam kegiatan pengelolaan wisata bahari. Dan agar dapat memperoleh pendapatan yang lebih baik daripada hanya sekedar menjadi seorang nelayan.

- Hubungan yang saling menguntungkan antara wisata bahari dengan masyarakat lokal

Pesatnya perkembangan kegiatan wisata bahari di kelurahan Sanur Kelod sehingga membawa banyak keuntungan dalam berbagai bidang bagi masyarakat lokal disana. Hal ini menjadi salah satu faktor yang menjadi motivasi masyarakat lokal untuk ikut terlibat secara aktif berpartisipasi dalam pengelolaan wisata bahari di Pantai Semawang kelurahan Sanur Kelod. Dengan adanya partisipasi masyarakat lokal dalam pengelolaan wisata bahari di kelurahan kelurahan Sanur Kelod, maka akan berpengaruh terhadap pengembangan wisata bahari di Pantai Semawang kelurahan Sanur Kelod. Semakin berkembangnya wisata bahari akan mendatangkan banyak keuntungan bagi masyarakat lokal. Keuntungan yang diperoleh meliputi peningkatan pendapatan masyarakat lokal, 
peningkatan kesejahteraan hidup, status sosial dan sebagainya.

\subsection{Partisipasi Masyarakat Lokal dalam Pengelolaan Wisata Bahari di Pantai Semawang Kelurahan Sanur Kelod}

Dalam pengelolaan wisata bahari di Pantai Semawang Kelurahan Sanur Kelod, masyarakat, pengusaha serta pemerintah saling bekerjasama dalam segala hal untuk mewujudkan pariwisata berkelanjutan di Pantai Semawang Kelurahan Sanur Kelod. Dalam prakteknya, digunakan prinsip prinsip manajemen berkelanjutan yaitu

\section{- Partisipasi dalam Bidang Ekonomi}

Partisipasi masyarakat lokal di Pantai Semawang Kelurahan Sanur Kelod di bidang ekonomi adalah dengan bekerja sebagai karyawan di bidang wisata bahari, selain itu berwiraswasta di berbagai bidang seperti membuka warung makan, kios cinderamata, kios yang menjual keperluan wisatawan dan lainnya. Saat ini hampir seluruh masyarakat lokal mendirikan usaha di bidang jasa wisata bahari, seperti contohnya perusahaan sea walker, scuba diving, free diving, dan penyewaan kano serta penyewaan boat.

- Partisipasi dalam Bidang Lingkungan

Adapun bentuk partisipasi masyarakat lokal di Pantai Semawang Kelurahan Sanur Kelod dalam bidang lingkungan dapat dilihat dalam berbagai bentuk, antara lain : program pembersihan Pantai Semawang yang dilakukan secara rutin oleh masyarakat lokal dan dari berbagai instansi juga turut serta berpartisipasi, program pembersihan terumbu karang merupakan program yang dirancang untuk melestarikan dan mejaga kebersihan terumbu karang di Pantai Semawang, adanya musyawarah masyarakat yang dilakukan secara rutin untuk membahas berbagai hal di bidang lingkungan yang perlu dibenahi, adanya partisipasi dari masyarakat lokal dalam upaya menjaga keamanan lingkungan atau biasa disebut dengan pecalang di seputaran kawasan Pantai Semawang, adanya partisipasi dari masyarakat lokal di Pantai Semawang yang meminjamkan tanah kosong mereka untuk dijadikan tempat parkir kendaraan wisatawan yang berkunjung ke Pantai Semawang.

- Partisipasi dalam Bidang Sosial Budaya

Bentuk partisipasi masyarakat lokal dalam pengelolaan wisata bahari di Pantai Semawang Kelurahan Sanur Kelod berdasarkan prinsip manajemen berkelanjutan pada bidang sosial budaya dapat dilihat dalam berbagai hal, seperti terdapat program peletakan patung - patung khas Bali dan patung selamat datang yang diletakan di setiap tempat tempat diving dan snorkeling. Hal ini dilakukan untuk melestarikan budaya lokal, serts untuk menarik minat wisatawan untuk melakukan diving dan snorkeling.

Berdasarkan uraian mengenai bentuk - bentuk partisipasi masyarakat lokal dalam pengelolaan wisata bahari di Pantai Semawang Kelurahan Sanur Kelod, dapat dikatakan bahwa bentuk partisipasi mereka termasuk dalam Spontaneous participation 
sebagaimana dikemukakan oleh Tosun (dalam Madiun, 2008 : 38).

Dijelaskan oleh Tosun bahwa partisipasi aktif bergerak dari bawah ke atas, yang merupakan partisipasi langsung dari masyarakat itu sendiri dalam membuat suatu perencanaan sampai pengambilan keputusan pada pengelolaan suatu kawasan.

\section{PENUTUP}

\subsection{Simpulan}

Berdasarkan hasil dari pembahasan yang telah diuraikan dapat diambil kesimpulan bahwa:

1. Motivasi untuk meningkatkan kesejahteraan hidup dan hubungan saling menguntungkan antara pariwisata bahari dengan masyarakat lokal di Pantai Semawang Kelurahan Sanur Kelod merupakan faktor - faktor yang menjadi motivasi masyarakat lokal untuk berpartisipasi dalam pengelolaan wisata bahari di Pantai Semawang Kelurahan Sanur Kelod.

2. Hasil penelitian menunjukan bentuk - bentuk partisipasi masyarakat dapat dibagi menjadi 3 bidang yaitu, partisipasi dalam bidang ekonomi antara lain : pengusaha di bidang wisata bahari adalah masyarakat lokal, seperti contohnya perusahaan sea walker, scuba diving, free diving, dan penyewaan kano serta penyewaan boat. Selain itu masyarakat lokal di Pantai Semawang Kelurahan Sanur Kelod juga membuka berbagai usaha dalam rangka memenuhi kebutuhan wisatawan di bidang wisata bahari, seperti contoh membuka warung makan, kios cinderamata, kios yang menjual berbagai keperluan wisatawan, dan lainnya. Partisipasi dalam bidang lingkungan antara lain : (1) program pembersihan Pantai Semawang, (2) program pembersihan terumbu karang, (3) adanya musyawarah masyarakat yang dilakukan untuk membahas berbagai hal di bidang lingkungan (4) adanya partisipasi masyarakat lokal dalam upaya pengamanan lingkungan di sekitar Pantai Semawang, (5) adanya partisipasi masyarakat lokal dalam peminjaman tanah kosong untuk dijadikan lahan parkir. Partisipasi dalam bidang sosial budaya, antara lain : program peletakan patung patung khas Bali.

\subsection{Saran}

Berdasarkan kesimpulan dari penelitian ini, maka dapat dijelaskan saran sebagai berikut:

1. Diharapkan pemerintah desa di area Sanur dapat membantu mempromosikan kawasan wisata Bahari di Pantai Semawang dengan lebih gencar terutama melalui media sosial.

2. Perlu adanya perhatian dari pemerintah mengenai pengadaan lahan parkir di Kelurahan Sanur Kelod sebagai penunjang kelancaran kegiatan wisata bahari di Pantai Semawang. Mengingat kendala yang dialami saat ini adalah keterbatasan lahan parkir.

3. Diharapkan warga sekitar tetap menjaga kebersihan bersama selain melakukan beach cleaning setiap bulannya. Hal tersebut dikarenakan kebersihan pantai Semawang secara terus menerus merupakan salah satu kunci kesuksesan wisata Bahari Pantai Semawang. 


\section{DAFTAR PUSTAKA}

Ajustawan, Putu 2005. “Keberadaan Jasa Penyewaan Kano sebagai Penunjang Kepariwisataan di Pantai Semawang Kelurahan Sanur Denpasar". Skripsi. Universitas Udayana Bali.

Arida, Nyoman Sukma. 2009. Ekowisata Bali. Denpasar : Udayana University Press.

Bungin, B. 2003. Analisis Data Penelitian Kualitatif. Jakarta : PT Raja Grafindo Perkasa.

Dalimunthe. 2007. "Partisipasi Masyarakat dalam Pengembangan Potensi Wisata Bahari Pantai Cermin Kabupaten Serdang Bedagai". Tesis. Sedang Bedagai.

Damardjati, R. 2015. Istilah-istilah Dunia Pariwisata Edisi Revisi. Jakarta : Pradnya Paramita.

Hasibuan, Malayu S.P., 2011. Manajemen Sumber Daya Manusia. Jakarta : Bumi Aksara.

Koentjaraningrat. 1994. Metode-metode Penelitian Masyarakat. Jakarta : PT Gramedia Pustaka Umum.

Madiun, I Nyoman. 2010. Nusa Dua Model Pengembangan Kawasan Wisata Modern. Denpasar : Universitas Udayana.

Miles, MB., dan Huberman, AM. 2007. Qualitative Data Analysis : A Sourcebook of New Methods. SAGE. Bevely Hills.

Moleong, Lexy J. 2013. Metodelogi Penelitian Kualitatif Edisi Revisi. Bandung : PT Remaja Rosdakarya.

Pitana, I Gde dan Diarta, I Ketut Surya. 2009. Pengantar Ilmu Pariwisata. Yogyakarta : Andi Yogyakarta.

Pendit, Nyoman S. 1999. Ilmu Pariwisata Sebuah Pengantar Perdana. Jakarta : Pradya Paramita.

Prasiasa, Dewa Putu Oka. 2013. Destinasi Pariwisata Berbasis Masyarakat. Jakarta : Salemba Humanika.

Saragi, Tumpal P. 2004. Mewujudkan Otonomi Masyarakat Desa. Jakarta : CV. Cipiruy.

Siagian, Sondang P. 1995. Manajemen Sumber Daya Manusia. Jakarta : Bumi Aksara.

Sugiono. 2013. Metodelogi Pemelitian Kuantitatif Kualitatif dan R\&D. Bandung : Alfabeta. 